\title{
Badania nad bezpieczeństwem GMO
}

\author{
Study on safety of GMO
}

\section{Ewelina Żmijewska}

\author{
Laboratorium Kontroli Genetycznie Modyfikowanych Organizmów, \\ Zakład Biotechnologii i Cytogenetyki Roślin \\ Instytut Hodowli i Aklimatyzacji Roślin — Państwowy Instytut Badawczy, Radzików \\ $\checkmark$ e-mail: e.zmijewska@ihar.edu.pl
}

\begin{abstract}
Zgodnie z prawodawstwem Unii Europejskiej rośliny zmodyfikowane genetycznie, przed wprowadzeniem na rynek muszą zostać ocenione pod względem bezpieczeństwa dla zdrowia ludzi, zdrowia zwierząt i środowiska. Jedyną rośliną GM, autoryzowaną do uprawy w Unii Europejskiej jest kukurydza MON810. Zawiera ona gen $c r y 1 A b$ $\mathrm{z}$ bakterii glebowej Bacillus thuringensis, warunkujący ekspresję białka Cry1Ab. Kukurydza jest często uprawiana w monokulturze, istnieje więc ryzyko akumulacji białka Cry1 Ab w glebie w wyniku wieloletniej uprawy.
\end{abstract}

Słowa kluczowe: GMO, CrylAb, Kukurydza

In accordance with European Union legislation, genetically modified plants must be evaluated for safety in terms of human health, animal health and the environment before being placed on the market. The only GM plant authorized for cultivation in the European Union is MON810 maize. It contains the cryl Ab gene from soil bacteria Bacillus thuringensis, which determines the expression of the Cryl Ab protein. Corn is often grown in monoculture, so there is a risk of accumulation of Cryl $\mathrm{Ab}$ protein in the soil as a result of many years of cultivation.

Key words: GMO, Cryl $A b$, maize

Zgodnie z prawodawstwem Unii Europejskiej rośliny zmodyfikowane genetycznie, na podstawie Rozporządzenia 1829/2003/WE i Dyrektywy 2001/18/WE przed wprowadzeniem na rynek muszą zostać ocenione pod względem bezpieczeństwa dla zdrowia ludzi, zdrowia zwierząt i środowiska.

Ocena ryzyka roślin GM w środowisku (ERA ang. Environmental Risk Assessment) jest przeprowadzana etapowo i obejmuje identyfikację elementów, które mogą spowodować niekorzystny wpływ, ocenę skutków potencjalnego niekorzystnego wpływu i prawdopodobieństwo ich wystąpienia, a także szacowanie ryzyka i stosowanie strategii zarządzania nim. Jeśli po jej przeprowadzeniu zostanie sprecyzowane prawdopodobne zagrożenie, wówczas po wprowadzeniu do obrotu prowadzane jest monitorowanie konkretnego przypadku (CSM ang. Case Specific Monitoring), określane także jako indywidualne i szczegółowe monitorowanie (Dyrektywa 2001/18/WE). Jeśli nie zostaną scharakteryzowane niekorzystne następstwa uprawy roślin genetycznie zmodyfikowanych w ERA, obligatoryjne jest prowadzenie ogólnego nadzoru środowiska (GS ang. General Surveillance), celem wykrycia nieoczekiwanych, przypuszczalnie negatywnych zmian $\mathrm{w}$ środowisku. Określony system monitorowania musi być zbieżny z celami ochrony środowiska, wliczając wybór adekwatnych metod, interakcję z innymi elementami monitorowania, wystandaryzowane dane $\mathrm{i}$ ich porównanie. Wedle wytycznych Europejskiego Urzędu ds. Bezpieczeństwa Żywności EFSA (ang. The European Food Safety Authority) istotne jest poznanie oraz ocena skutków uprawy roślin GM w różnych środowiskach i w uprawie wieloletniej.

Jedyną rośliną GM, autoryzowaną do uprawy w Unii Europejskiej jest kukurydza MON810. Zawiera ona gen crylAb $\mathrm{z}$ bakterii glebowej Bacillus thuringensis, warunkujący ekspresję białka Cry1Ab. Gen crylAb wprowadzono pod kontrolą konstytutywnego promotora $C a M V 35 S$, co skutkuje tym, że białko CrylAb jest syntetyzowane w kukurydzy MON810 w sposób ciągły, przez cały sezon wegetacyjny. Organizmy, których cykl życiowy jest związany z kukurydzą, są przez cały okres wzrostu i rozwoju roślin narażone na działanie białka Cry1Ab. Jako, że stężenie Cry1Ab w kukurydzy zmienia się w kolejnych fazach rozwojowych, zbadanie jego poziomu jest niezbędne do określenia stopnia ekspozycji poszczególnych organizmów w trakcie uprawy MON810.

$\mathrm{W}$ trakcie uprawy roślin i wraz z resztkami pożniwnymi transgeniczne białko może przedostawać się do gleby, wiążąc się z kwasami humusowymi i minerałami ilastymi, stając się niedostępnym dla działania mikroorganizmów rozkładających materię organiczną, zachowując przy tym działanie insektycydowe. Kukurydza jest często uprawiana w monokulturze, istnieje 
więc ryzyko akumulacji białka Cry1Ab w glebie w wyniku wieloletniej uprawy.

Zbadano stężenie białka Cry1Ab w różnych stadiach rozwojowych kukurydzy MON810, uprawianej na terenie Polski, w dwóch kolejnych latach badań. Wykorzystując uprawy kukurydzy zmodyfikowanej genetycznie, prowadzone w ramach projektu badawczego PBZ- MNiSW06/1/2007, określono stężenie białka Cry1Ab w glebie, w której uprawiano kukurydzę MON810.
Wykazano, że stężenie białka Cryl Ab w kukurydzy MON810 zależy od warunków meteorologicznych w poszczególnych latach uprawy i jest skorelowane pozytywnie z zawartością azotu ogólnego w roślinie. Nie stwierdzono obecności białka Cry1Ab w glebie, w której uprawiano kukurydzę MON810 przez 3 i 4 lata, co dowodzi braku akumulacji białka Cry1Ab w glebie w warunkach uprawy w Polsce. 